\title{
The Optimization of Irrigated Rice Field and Improvement of Land Productivity Throught Development of Rice-Shrimp (Macrobrachium rosenbergii) Cultivation Technology on Bantul Regency
}

\author{
Damasus Riyanto ${ }^{1, *}$, Arif Anshori ${ }^{1}$, Kurnianita Triwidyastuti $^{1}$ and Yustisia $^{2}$ \\ ${ }^{1}$ Yogyakarta Assessment Institute of Agricultural Technology, \\ Stadion Maguwoharjo Street No.12, Karangsari, Wedomartani, Ngemplak - Sleman, Yogyakarta \\ Special Region, Indonesia \\ ${ }^{2}$ South Sumatra Assessment Institute for Agriculture Technology \\ Colonel H. Barlian Street Km.6, Srijaya, Alang-alang Lebar - Palembang, South Sumatra, Indonesia
}

\begin{abstract}
Transition of productive irrigated rice fields into other forms makes agricultural sector have to optimized using its field. Purpose of study was to determine application rice-shrimp technology on soil chemical properties, rice productivity, and economical feasibility. Treatments applied were $\mathrm{U}_{1}=$ Control/ technology used by local farmers, $\mathrm{U}_{2}=$ Rice-Shrimp cultivation by shrimp population 4,000 tails, $\mathrm{U}_{3}=$ population $6,000, \mathrm{U}_{4}=$ population $8,000, \mathrm{U}_{5}=$ Shrimp population $4,000+$ rice husk $400 \mathrm{~kg}, \mathrm{U}_{6}=$ population $6,000+$ husk $400 \mathrm{~kg}, \mathrm{U}_{7}=$ population $8,000+$ husk $400 \mathrm{~kg}$. The research design was completely randomized block and replicated three times. Results showed number of shrimp populations did not significantly affect to change soil $\mathrm{pH}$, Eh value, level of $\mathrm{Fe}$, and $\mathrm{Mg}$, but had a significant effect on $\mathrm{C}$-organic, $\mathrm{N}$-total, available $\mathrm{P}$ and $\mathrm{K}, \mathrm{CEC}$. Application of husk as $400 \mathrm{~kg}$ and shrimp population up to 6,000 tails had a significantly effect on the number of tillers, grains per panicle, fresh biomass weight, rice yields up to $43.26 \%$ and net profit up to $269.14 \%$ compared to control by $\mathrm{BC}$ and $\mathrm{RC}$ ratios are 1.92 and 2.93 , respectively while $\mathrm{MBCR}$ is 3.34 . It means rice-shrimp technology on Bantul classified as feasible.
\end{abstract}

\section{Introduction}

The transition of productive irrigated rice fields into other forms such as housing area, apartments and industrial area have made the agricultural sector shall be worked hard to fullfill the food needs in the midst of the constraints on the area of agriculture which has decreased from year to year, both in terms of the number, area and quality of agricultural land. In addition, Widodo et al. [1] stated that increasing the number of population causes

*Corresponding author: damasusriyanto@gmail.com 
the food needs or food supply to increase in productivity. The fact that is happening in the field is that the increase in population is not matched by existing agricultural production. Therefore, this is a challenge for all stakeholders to create an area that is still capable of realizing food security. Furthermore, to achieve food security, the agricultural sector is required to play its role amidst the decreasing land area. One of the things that the agricultural sector can do it is to make new breakthroughs in order to survive in limited national food stock condition. New breakthroughs in the agricultural sector include the development of Mina-Padi cultivation technology [2].

According to Akbar [3, 4, 5, 6] Mina-padi farming is a fish rearing system that is carried out together with rice in the fields. Mina Padi cultivation is an integrated cultivation that can increase the productivity of paddy fields and also produce fish. While Rice-shrimp cultivation is a technology that combines shrimp with rice cultivation in the same field. This system has several advantages, among others : farmers will get additional income from fish or shrimp without reducing income from rice, increase rice production, increase efficiency and land productivity, rice plants become more controlled and meet the animal protein needs of farmers. Dewani et al. [7] stated that, the Mina-padi farming system cultivating fish with rice or raising fish between rice plants. This is intended so that the benefits obtained from this method aim on multiple results, namely: from the rice itself and from fish or shrimp on the same field. Nadira et al. [8], [9] also added that there are other benefits obtained through raising fish in rice fields, namely that it can reduce pests and diseases in rice plants and increase soil fertility.

During application of Minapadi cultivation system, rice planting was used the jajar legowo system, which is a technological agriculture to obtain a plant population of more than 160,000 per hectare. In addition, Prasetyo and Kadir [10] stated that the application of the jajar legowo system aside to increasing the cropping population, it is also that rice plants are able to photosynthesize better than conventional rice planting system. The application of jajar legowo planting system is recommended to use a $25 \mathrm{~cm}$ spacing between clumps in rows; $12.5 \mathrm{~cm}$ spacing in rows; and $40 \mathrm{~cm}$ as the distance between rows or it can be written $(25 \times 12,5 \times 40) \mathrm{cm}$. The rice planting pattern with the jajar legowo row system recommended by the Ministry of Agriculture has benefits and advantages for rice farmers. [11] these benefits can be obtained from several aspects such as increasing population size, ease of maintenance, reducing pest populations especially rats pest, saving fertilization costs, and increasing the quality and quantity of grain production.

Some researchs stated that the fish or shrimp harvested from rice fields are often the main source of protein for farmers. Shrimp cultivation in the rice-shrimp system in lowland rice field provides greater economically benefits for farmers, especially from shrimp harvests because the price is quite good [12]. Some results of field test have shown that farmers' profits increase by including fish / shrimp into the rice production system, by knowing the optimum fish / shrimp population per land area, it is hoped that rice growth and production will not be disturbed and farmers' income will be improved both from rice yields and fish / shrimp harvest. The application of rice-shrimp cultivation is carried out in technically or semi-technical irrigated rice fields because the presence of water in the paddy fields is very much needed. Another advantage of the Rice-shrimp cultivation system is that farmers can save fertilizers because the irrigation water is mixed with shrimp manure and organic shrimp food, which can minimize the use of chemical fertilizers. According to Damayanti $[13,14,15]$ a number of benefits obtained by farmers by implementing riceshrimp include fertile rice fields with shrimp manure that contains various nutrients so that it can reduce the use of fertilizers which will have a positive impact on reducing methane gas $\left(\mathrm{CH}_{4}\right)$ produced from the residual inorganic fertilization.

Furthermore Allahyari and Noorhosseini [16],[17] stated that minapadi or rice-shrimp farming can reduce pollution and ensure environmental sustainability through reducing the 
use of chemical pesticides and fertilizers, increasing the income of rice farmers, and increasing the fertility of their rice fields. According to Grassi et al. [18], [19, 20] the riceshrimp yearly brings in a gross return 2.4 times higher than rice- rice (US\$2 838/ ha versus US $\$ 1186 /$ ha). However, because the cost of material inputs for rice-shrimp production is over four times higher than it is for rice-rice production, the BCR for rice-shrimp is actually slightly lower than it is for rice-rice (the rice-shrimp system brings in US\$2.13 for every dollar spent and rice-rice US\$2.20). This brings to light another important difference between the two systems: the high cost of material inputs required for shrimp production makes engaging in rice-shrimp a financially risky enterprise for smallholders.

The purpose of this study was to determine the application of Rice-Shrimp cultivation technology to soil chemical properties, the productivity of rice plants, and the economic feasibility of the farming system compare to the rice monoculture cultivation in irrigated rice fields of Bantul Regency.

\section{Material and Method}

\subsection{Time and place of the research}

The research of optimization irrigated rice field throught the development of Rice-Shrimp was conducted on Planting Season II (February - May 2020) in Kebon Agung village, Imogiri District, Bantul Regency. This activity involved the Local extension agents and under the guidance of the Agriculture and Fisheries Office of Bantul Regency also it was assisted by the staff researcher from Yogyakarta AIAT.

\subsection{Material of the research}

The research materials were used Inpari 42 Green Super Rice and Ciherang rice seed varieties, shrimp fry (age about 3 month), agricultural lime, shrimp feed. The chemical fertilizers were used Urea, $\mathrm{KCl}$ and NPK Phonska (15:15:15). Organic manure used cattle manure by dose of 5 ton.ha ${ }^{-1}$

The equipment research were used a set of soil test kit for rice field samples, soil tillage equipment, a field knife, ring sample, field length measurement, a hoe, harvesting tools, a sickle and a pedal threser for harvesting rice grain, plastic sample, plastic bucket volume 20 litre, bamboo, sack, paper label, digital balancing scales, $\mathrm{pH}$ meter and net for shrimp harvesting.

\subsection{The implementation of rice-shrimp cultivation}

The assessment was carried out on a stretch of irrigated rice fields that have water flows easily and it is not contaminated by industrial waste materials. The research operations assisted by cooperator farmers (on farm research) with a total area about 0.6 ha. The kinds of technological treatments consisted of 7 technology packages, which each of package was repeated 3 times or the field of cooperator farmer as the replications. The treatments of tehnological innovation namely : $U_{1}=$ control/ technology used by local farmers which apply monoculture rice farming (without rice-shrimp cultivation), $\mathrm{U}_{2}=$ rice-shrimp cultivation with a density of shrimp 4,000 tail, $\mathrm{U}_{3}=$ rice-shrimp cultivation with a density of shrimp 6,000 tails, $\mathrm{U}_{4}=$ rice-shrimp cultivation with a density of shrimp 8,000 tails, $\mathrm{U}_{5}=$ rice-shrimp cultivation with a density of shrimp 4,000 tail plus rice husk $400 \mathrm{~kg}, \mathrm{U}_{6}=$ rice-shrimp cultivation with a density of shrimp 6,000 tails plus rice husk $400 \mathrm{~kg}, \mathrm{U}_{7}=$ rice-shrimp 
cultivation with a density of shrimp 8,000 tail plus rice husk $400 \mathrm{~kg}$. Every treatment occupies an area of $1,000 \mathrm{~m}^{2}$ of the rice field owned by farmers.

The maximum age of the rice seedlings to be planted is 15 days from the time of the seeds which is sown in the field. The basic fertilizer of rice plants are Ponska NPK (15:15:15) fertilizer as much as $250 \mathrm{~kg} \cdot \mathrm{ha}^{-1}$, Urea fertilizer $150 \mathrm{~kg} \cdot \mathrm{ha}^{-1}$ (given 2 times, which were $7 \mathrm{DAS}$ and $35 \mathrm{DAS}$ ) then $\mathrm{KCl}$ as much as $75 \mathrm{~kg}^{-h^{-1}}$ (given 2 times), while the organic manure was given as much as 5 ton. $\mathrm{ha}^{-1}$. The provision of irrigation water for rice plants was carried out by intermmiten irrigation system and the first irrigation is done when the rice plants were at 8 days after transplanting with a water height about $5 \mathrm{~cm}$ above the field ground.

The size of pond in the rice field is shown on Figure 1. The wide pond for shrimp storage is $200 \mathrm{~cm}$ and the depth of pond is about $80 \mathrm{~cm}$, while the depth of the trench rice field around $60 \mathrm{~cm}$ and width of pond is $150 \mathrm{~cm}$.

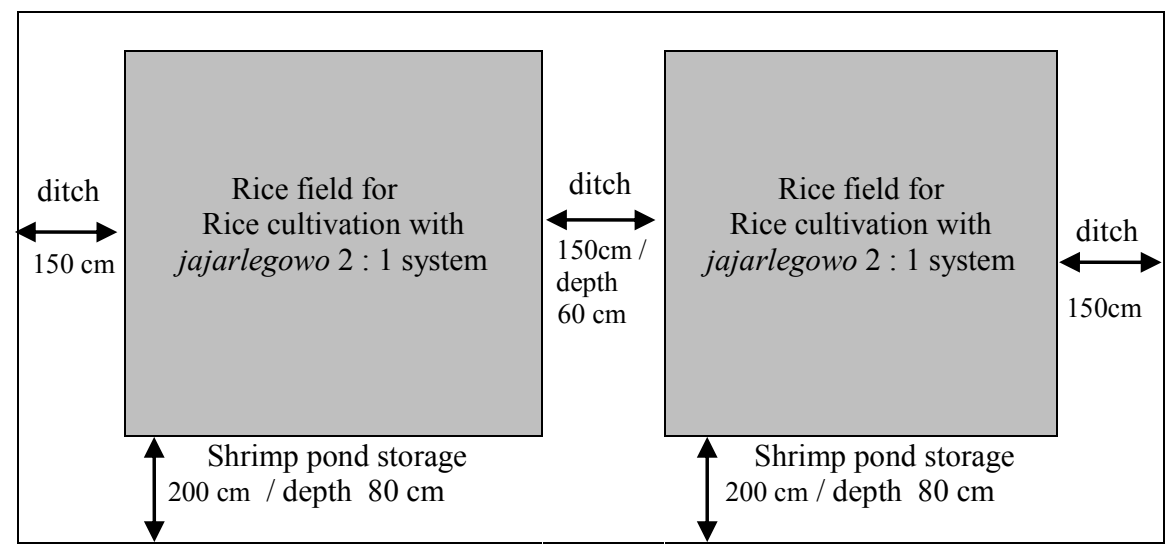

Fig.1. The size of shrimp pond for rice-shrimp cultivation

The shrimp frys are spread to the rice field (rearing pond) at about 2 month from the time of nursery shrimp eggs and they are free from pests / diseases and predatory animals. The stocking application should be done in the afternoon or night so that the giant shrimp do not experience stress. The spread of giant shrimp is carried out based on the density standard of the biota, for the optimum density is around 5,000-6,000 shimp tails $/ 1,000 \mathrm{~m}^{2}$.

Providing the shelters as a place of shrimp shelter / footing, in the form of a net with bamboo sticking at the ends and then put the water hyacinth plants (Eichhornia crassipes) on surroundings that place. The $\mathrm{pH}$ optimum of water in the shrimp pond is around $7.5-8.5$ which is measured regularly by $\mathrm{pH}$ meter. If the $\mathrm{pH}$ is low it is necessary to add lime, while if the $\mathrm{pH}$ is high it is necessary to add irrigated new clean water.

The total feed of shrimp is given in accordance with the number of shrimp that is maintained. The time of feeding is morning and evening with the largest portion of feed at the night. For prawn feed, pellets (30\% protein) are given as much as $1 \%$ of the body weight of shrimp / day with a frequency of feeding 2 times a day.

The data originating from rice-shrimp cultivation system were analyzed by the SAS version 9.0 program to determine the response of some treatments, which was applied by the analysis of variance. Furthermore, to differentiate the significance between treatments, it was continued with Duncan's Multiple RangeTest with a significance level of 5\%. 


\section{Result and Discussion}

\subsection{The application of rice-shrimp cultivation on rice field fertility}

The development farming system, which is consider on environmentally friendly and low inputs production, is one way to increase the farmer income and their families, because the applied technology in the system have considered the importance of interactions between components and their relation to activities outside the agricultural system and the importance of the role of bio-physical, socio-cultural, institutional and economic conditions of farmer community groups.

The integrated farming system of rice-shrimp cultivation on irrigated rice field can be increased the paddy field productivity and soil fertility. In rice-shrimp cultivation, farmers usually use a lower dose of chemical fertilizer than the region recommended dose, because of the ecological correlation between the amount of feed and shrimp cultivation. The excess feed that is not consumed by shrimp will be overhauled by microbes and become natural fertilizer for the soil and water. This condition are presented on Table 1a and $1 \mathrm{~b}$ that showed the chemical soil characteristic before application of rice-shrimp cultivation and after application based on shrimp densities. The soil $\mathrm{pH}$ before application on all plots of rice field was shown above 6.8 then after application of rice-shrimp cultivation the $\mathrm{pH}$ soil on rice monoculture plots relatively fix, but on rice-shrimp plots are slightly decreased in $\mathrm{pH}$ due to the decomposition of organic matter derived from shrimp manure and feed residue (Table 1a and $1 \mathrm{~b}$ ). The content of $\mathrm{N}$-total, $\mathrm{C}$-org, $\mathrm{P}$ and $\mathrm{K}$ available and CEC soil after the application showed a significant increase compared to monoculture rice cultivation systems, especially in the technology package $F$ (population of shrimp 6,000 tail/1,000 $\mathrm{m}^{2}$, used Inpari 42 rice variety + rice husk $400 \mathrm{~kg} / 1,000 \mathrm{~m}^{2}$ ).

Table 1a. The chemical soil characteristic before application of rice-shrimp cultivation

\begin{tabular}{|c|l|c|c|c|c|c|c|}
\hline Code & \multicolumn{1}{|c|}{ Treatments } & $\begin{array}{c}\text { Soil pH } \\
\left(\mathrm{H}_{2} \mathrm{O}\right)\end{array}$ & $\begin{array}{c}\mathrm{N} \text { total } \\
(\%)\end{array}$ & $\begin{array}{c}\text { C-org. } \\
(\%)\end{array}$ & $\begin{array}{c}\text { P-avail. } \\
(\mathrm{ppm})\end{array}$ & $\begin{array}{c}\text { K-avail. } \\
(\mathrm{me} / 100 \mathrm{~g})\end{array}$ & $\begin{array}{c}\text { CEC } \\
(\mathrm{me} / 100 \mathrm{~g})\end{array}$ \\
\hline $\mathbf{A}$ & $\begin{array}{l}\text { Rice monoculture } \\
\text { (Farmer treatment) } \\
\text { Ciherang rice variety }\end{array}$ & 6.8 & 0.14 & 1.16 & 14.27 & 2.87 & 23.32 \\
\hline $\mathbf{B}$ & $\begin{array}{l}\text { R-S cultivation } \\
\text { shrimp density 4,000 } \\
\text { Inpari 42 rice variety }\end{array}$ & 6.7 & 0.17 & 1.18 & 13.48 & 2.65 & 28.46 \\
\hline $\mathbf{D}$ & $\begin{array}{l}\text { R-S cultivation } \\
\text { shrimp density 6,000 } \\
\text { Inpari 42 rice variety }\end{array}$ & 6.9 & 0.15 & 1.14 & 15.19 & 2.74 & 26.72 \\
\hline $\mathbf{D}$ & $\begin{array}{l}\text { R-S cultivation } \\
\text { shrimp density 8,000 } \\
\text { Inpari 42 rice variety }\end{array}$ & 6.8 & 0.16 & 1.12 & 12.53 & 2.41 & 22.81 \\
\hline $\mathbf{E}$ & $\begin{array}{l}\text { R-S cultivation } \\
\text { shrimp density 4,000 } \\
+ \text { Rice husk 400 kg } \\
\text { Inpari 42 rice variety }\end{array}$ & 6.9 & 0.13 & 1.19 & 14.17 & 2.26 & 29.64 \\
\hline F & $\begin{array}{l}\text { R-S cultivation } \\
\text { shrimp density 6,000 } \\
+ \text { Rice husk 400 kg } \\
\text { Inpari 42 rice variety }\end{array}$ & 7.0 & 0.18 & 1.17 & 13.46 & 2.53 & 30.37 \\
\hline & $\begin{array}{l}\text { R-S cultivation } \\
\text { shrimp density 8,000 } \\
+ \text { Rice husk 400 kg } \\
\text { Inpari 42 rice variety }\end{array}$ & 6.9 & 0.14 & 1.15 & 15.95 & 2.48 & 26.75 \\
\hline
\end{tabular}


According to Sismiyati et al. [21,22,23], generally organic materials available and utilized include plant residues or forage plant. Furthermore Nugroho et al. [24,25,26,27], stated that in the process of decomposition of organic matter will produce organic acids, so it causing the $\mathrm{pH}$ soil to drop.

The use of rice-shrimp cultivation system is carried out for efforts to utilize land so that rice field can be used optimally and efficiently. This utilizes shrimp manure system to increase soil fertility by improve the physical, chemical and biological properties of the soil. Amino acids found in protein shrimp feed and ammonia derived from shrimp waste have the potential to become nitrogen elements plants need. Soils in paddy fields with inundation will induce electrochemical changes that affect the supply and nutrient uptake.

Tabel $\mathbf{1 b}$. The chemical soil characteristic after application of rice-shrimp cultivation base on shrimp dentisities

\begin{tabular}{|c|l|c|c|c|c|c|c|}
\hline Code & \multicolumn{1}{|c|}{ Treatment } & $\begin{array}{c}\text { Soil pH } \\
\left(\mathrm{H}_{2} \mathrm{O}\right)\end{array}$ & $\begin{array}{c}\text { N total } \\
(\%)\end{array}$ & $\begin{array}{c}\text { C-org. } \\
(\%)\end{array}$ & $\begin{array}{c}\text { P.avail } \\
(\mathrm{ppm})\end{array}$ & $\begin{array}{c}\text { K.avail } \\
(\mathrm{me} / 100 \mathrm{~g})\end{array}$ & $\begin{array}{c}\text { CEC } \\
(\mathrm{me} / 100 \mathrm{~g})\end{array}$ \\
\hline $\mathbf{A}$ & $\begin{array}{l}\text { Rice monoculture } \\
\text { (Farmer treatment) } \\
\text { Ciherang rice variety }\end{array}$ & $6.9 \mathrm{a}$ & $0.10 \mathrm{a}$ & $1.14 \mathrm{a}$ & $11.34 \mathrm{a}$ & $2.15 \mathrm{a}$ & $22.68 \mathrm{a}$ \\
\hline $\mathbf{B}$ & $\begin{array}{l}\text { R-S cultivation } \\
\text { shrimp density 4,000 } \\
\text { Inpari 42 rice variety }\end{array}$ & $6.8 \mathrm{a}$ & $0.21 \mathrm{~b}$ & $1.73 \mathrm{~b}$ & $17.62 \mathrm{~b}$ & $3.21 \mathrm{~b}$ & $30.27 \mathrm{~b}$ \\
\hline $\mathbf{C}$ & $\begin{array}{l}\text { R-S cultivation } \\
\text { shrimp density 6,000 } \\
\text { Inpari 42 rice variety }\end{array}$ & $6.8 \mathrm{a}$ & $0.26 \mathrm{bc}$ & $2.28 \mathrm{bc}$ & $16.09 \mathrm{~b}$ & $3.62 \mathrm{bc}$ & $33.81 \mathrm{~b}$ \\
\hline $\mathbf{D}$ & $\begin{array}{l}\text { R-S cultivation } \\
\text { shrimp density 8,000 } \\
\text { Inpari 42 rice variety }\end{array}$ & $6.7 \mathrm{~b}$ & $0.24 \mathrm{~b}$ & $2.15 \mathrm{bc}$ & $18.61 \mathrm{~b}$ & $3.45 \mathrm{bc}$ & $32.63 \mathrm{~b}$ \\
\hline $\mathbf{E}$ & $\begin{array}{l}\text { R-S cultivation } \\
\text { shrimp density 4,000 } \\
+ \text { Rice husk 400 kg } \\
\text { Inpari 42 rice variety }\end{array}$ & $6.8 \mathrm{a}$ & $0.25 \mathrm{bc}$ & $2.04 \mathrm{~b}$ & $17.58 \mathrm{~b}$ & $3.37 \mathrm{~b}$ & $34.05 \mathrm{bc}$ \\
\hline $\mathbf{F}$ & $\begin{array}{l}\text { R-S cultivation } \\
\text { shrimp density 6,000 } \\
+ \text { Rice husk 400 kg } \\
\text { Inpari 42 rice variety }\end{array}$ & $6.7 \mathrm{a}$ & $0.29 \mathrm{c}$ & $2.57 \mathrm{c}$ & $21.37 \mathrm{c}$ & $3.94 \mathrm{c}$ & $38.74 \mathrm{c}$ \\
\hline & $\begin{array}{l}\text { R-S cultivation } \\
\text { shrimp density 8,000 } \\
+ \text { Rice husk 400 kg } \\
\text { Inpari 42 rice variety }\end{array}$ & $6.8 \mathrm{a}$ & $0.28 \mathrm{c}$ & $2.49 \mathrm{c}$ & $20.24 \mathrm{c}$ & $3.78 \mathrm{c}$ & $36.38 \mathrm{c}$ \\
\hline
\end{tabular}

* The numbers accompanied by the same letter in one column are not significantly different based on DMRT on the $5 \%$ level

\subsection{The effect of rice-shrimp cultivation on plant growth and yield}

One of the optimization of the potential of irrigated rice fields and increasing farmers' income is by designing the land with appropriate technology. The way that can be done is by changing the agricultural strategy from a monoculture system to an agricultural diversification system, one of which is by applying the rice-shrimp cultivation technology with the jajar legowo 2:1 planting system. In addition, the jajar legowo 2 :1 planting system is designed by manipulating rice plants so that they are made into more edges. Those located on the side rows will result in higher production and better grain quality because this side of the plants will get more sunlight then the process of photosynthesis can run well.

Moreover Nurhayati et al. [28], [29], give stated that rice-fish with legowo system as an engineering plant by adjusting a spacing between the clumps and widening the distance between rows so that it is as the rice clumps are on the edge of the crop which benefits as 
side plants (border effect). In the Jajar legowo 2:1 planting system each of the two rows of rice plants empty interspersed with wide row spacing twice in a row. While plant spacing in the row that extends narrowed down to half a spacing in the row.

Performance of rice yields and farmers' income can also increase soil fertility and reduce pest attacks on rice plants. The legowo technology is an designal technique of planting by adjusting the spacing between clumps and between rows so that there is compaction of the rice clumps in rows and

The results of observations of rice growth using rice-shrimp jajar legowo technology and farmers' existing systems using conventional technology are shown in Table 2 below.

Table 2. Observation of plant height and the number of tiller on various treatments

\begin{tabular}{|c|c|c|c|c|c|c|}
\hline Code & Treatments & $\begin{array}{c}\text { Plant } \\
\text { height } \\
21 \text { DAP } \\
(\mathrm{cm})\end{array}$ & $\begin{array}{c}\text { Plant } \\
\text { height } \\
45 \text { DAP } \\
(\mathrm{cm})\end{array}$ & $\begin{array}{l}\text { Plant } \\
\text { height } \\
60 \text { DAP } \\
(\mathrm{cm})\end{array}$ & $\begin{array}{c}\text { The number of } \\
\text { tiller on } 21 \\
\text { DAP }\end{array}$ & $\begin{array}{c}\text { The number } \\
\text { of tiller on } \\
45 \text { DAP }\end{array}$ \\
\hline A & $\begin{array}{l}\text { Rice monoculture } \\
\text { (Farmer treatment) } \\
\text { Rice variety Ciherang } \\
\end{array}$ & 45.63 & 79.15 & $90.79 \mathrm{c}$ & 16.48 & $22.68 \mathrm{a}$ \\
\hline B & $\begin{array}{l}\text { R-S cultivation } \\
\text { shrimp density 4,000 } \\
\text { Rice variety Inpari } 42 \\
\end{array}$ & 50.72 & 93.26 & $102,58 \mathrm{~b}$ & 14.65 & $18.79 \mathrm{c}$ \\
\hline $\mathrm{C}$ & $\begin{array}{l}\text { R-S cultivation } \\
\text { shrimp density } 6,000 \\
\text { Rice variety Inpari } 42\end{array}$ & 51.46 & 94.74 & $103.26 \mathrm{~b}$ & 13.37 & $19.15 \mathrm{a}$ \\
\hline D & $\begin{array}{l}\text { R-S cultivation } \\
\text { shrimp density } 8,000 \\
\text { Rice variety Inpari } 42 \\
\end{array}$ & 51.63 & 93.29 & $104.62 \mathrm{~b}$ & 14.78 & $19.75 \mathrm{bc}$ \\
\hline $\mathrm{E}$ & $\begin{array}{l}\text { R-S cultivation } \\
\text { shrimp density 4,000 } \\
\text { Rice variety Inpari } 42+ \\
\text { Rice husk } 400 \mathrm{~kg}\end{array}$ & 51.94 & 94.62 & $103.78 \mathrm{~b}$ & 14.97 & $20.19 b$ \\
\hline $\mathrm{F}$ & $\begin{array}{l}\text { R-S cultivation } \\
\text { shrimp density } 6,000 \\
\text { Rice variety Inpari } 42+ \\
\text { Rice husk } 400 \mathrm{~kg}\end{array}$ & 52.17 & 95.48 & $108.43 \mathrm{a}$ & 15.37 & $20.74 b$ \\
\hline G & $\begin{array}{l}\text { R-S cultivation } \\
\text { shrimp density } 8,000 \\
\text { Rice variety Inpari } 42+ \\
\text { Rice husk } 400 \mathrm{~kg}\end{array}$ & 53.84 & 93.17 & $107.24 \mathrm{a}$ & 15.04 & $20.26 \mathrm{~b}$ \\
\hline
\end{tabular}

* The numbers accompanied by the same letter in one column are not significantly different based on DMRT on the $5 \%$ level

Based on the table above, it is proven that rice fields with the application of rice-shrimp (technology package innovation) are able to make better plant growth due to the application of the jajar legowo 2:1 (40 x $12.5 \times 25 \mathrm{~cm})$ system, while in the existing land farmers still used tile planting system $(20 \times 20 \mathrm{~cm})$.

In the observation of maximum plant height growth at the age of $60 \mathrm{DAP}$, the application of the introduction of package D, E, F and $\mathrm{G}$ with a population of about 6,000 up to 8,000 shrimps per $1,000 \mathrm{~m}^{2}$ have a higher productivity than package B (the total population of shrimp is around 4000 heads) and the existing land of local farmers, package A so this will stimulate plant growth. Rice to produce better rice. This is in accordance with the statement of Ikhwani et al. [30],[31,32,33], who stated that the advantage of the jajar legowo planting system is that put more plants become in border side (border effect). This cropping system manipulates the layout of the plants, so that the rice plants are mostly have sunlight in carry out the photosyntetic process, good air circulation, more evenly distributed 
nutrients, and easier maintenance of plant growth because of the wider aisle distance, resulting in higher grain with better quality.

The result of study from [34],[35], give stated that, the number of tillers will be maximized if the plant has good genetic characteristics coupled with favorable environmental conditions or in accordance with plant growth and development. The maximum number of tillers is also determined by the spacing, because the spacing determines solar radiation, mineral nutrients and the cultivation of the plant itself. According to Siavoshi et al. [36], the number of tiller will be maximized if the plant has good genetic characteristics coupled with favorable environmental conditions or in accordance with plant parts and plant development.

Furthermore, the effect of the application rice-shrimp cultivation system with various densities on the yield components is presented in table 3 below.

Table 3. The observation of rice yield component on various treatments at Kebon Agung village, Imogiri District, Bantul

\begin{tabular}{|c|c|c|c|c|c|c|}
\hline Code & Treatments & $\begin{array}{l}\text { Length of } \\
\text { panicles }\end{array}$ & $\begin{array}{c}\text { The } \\
\text { number of } \\
\text { panicles per } \\
\text { clumps }\end{array}$ & $\begin{array}{l}\text { The } \\
\text { number of } \\
\text { grains per } \\
\text { panicle }\end{array}$ & $\begin{array}{l}\text { The } \\
\text { number of } \\
\text { filled grain } \\
\text { per panicle }\end{array}$ & $\begin{array}{c}\text { The weight } \\
\text { of } 1,000 \\
\text { grains }\end{array}$ \\
\hline A & $\begin{array}{l}\text { Rice monoculture } \\
\text { (Farmer treatment) } \\
\text { Rice variety Ciherang }\end{array}$ & $21.74 \mathrm{c}$ & $23,48 \mathrm{a}$ & $146.34 \mathrm{~d}$ & 115.62 & $24.13 \mathrm{c}$ \\
\hline B & $\begin{array}{l}\text { R-S cultivation } \\
\text { shrimp density } 4,000 \\
\text { Rice variety Inpari } 42\end{array}$ & $25.23 \mathrm{ab}$ & $19.47 \mathrm{c}$ & $194.65 \mathrm{c}$ & 171.82 & $27.37 \mathrm{ab}$ \\
\hline $\mathrm{C}$ & $\begin{array}{l}\text { R-S cultivation } \\
\text { shrimp density } 6,000 \\
\text { Rice variety Inpari } 42\end{array}$ & $24.69 \mathrm{a}$ & $20.19 \mathrm{bc}$ & $209.37 \mathrm{~b}$ & 174.51 & $28.16 \mathrm{a}$ \\
\hline $\mathrm{D}$ & $\begin{array}{l}\text { R-S cultivation } \\
\text { shrimp density } 8,000 \\
\text { Rice variety Inpari } 42\end{array}$ & $23.53 \mathrm{~b}$ & $19.68 \mathrm{c}$ & $211.24 \mathrm{~b}$ & 173.68 & $26.81 \mathrm{~b}$ \\
\hline E & $\begin{array}{l}\text { R-S cultivation } \\
\text { shrimp density } 4,000 \\
\text { Rice variety Inpari } 42 \\
\text { + Rice husk } 400 \mathrm{~kg}\end{array}$ & $25.84 \mathrm{ab}$ & $20.59 \mathrm{bc}$ & $212.72 b$ & 184.55 & $27.92 \mathrm{ab}$ \\
\hline $\mathrm{F}$ & $\begin{array}{l}\text { R-S cultivation } \\
\text { shrimp density } 6,000 \\
\text { Rice variety Inpari } 42 \\
\text { + Rice husk } 400 \mathrm{~kg}\end{array}$ & $26.64 \mathrm{a}$ & $21.73 b$ & $223.51 \mathrm{a}$ & 189.73. & $28.75 \mathrm{a}$ \\
\hline G & $\begin{array}{l}\text { R-S cultivation } \\
\text { shrimp density } 8,000 \\
\text { Rice variety Inpari } 42 \\
\text { + Rice husk } 400 \mathrm{~kg}\end{array}$ & $26.82 \mathrm{a}$ & $21.47 \mathrm{~b}$ & $219.51 \mathrm{a}$ & 186.43 & $28.27 \mathrm{a}$ \\
\hline
\end{tabular}

* The numbers accompanied by the same letter in one column are not significantly different based on DMRT on the $5 \%$ level

Based on the data in Table 3, it is shown that the Inpari 42 rice variety has advantages in panicle length, the number of grains per panicle and the weight of 1,000 grains are higher than the Ciherang variety and its significantly different, while the number of panicles per clump for Ciherang is higher than Inpari 42 in various treatments.

The weight of 1,000 grains of grain is influenced by the growing environment of the plant such as the availability of nutrients in the soil during rice cultivation. Lack of nutrients at the time of planting will result in the weight of 1000 grains of grain produced being lower than it should be. The Ciherang variety in farmer conventional planting methods gave the lower weight of 1,000 grains and was significantly different from inpari 42 in various treatments. In accordance with Sitohang [37], who stated that the special characteristics and traits possessed by each variety appear different because of the genetic differences of each variety. This is supported by the results of Talihun [38] and Misran 
research's [39] were shown that the row planting system has a significant effect on the yield and yield components of rice, especially on the panicle length, number of grain per panicle, dried grain yield and 1,000 grains weight.

Table 4. The observation of harvesting rice biomass, weight of dried rice yield and weight of dried grind on various treatments of rice-shrimp cultivation

\begin{tabular}{|c|c|c|c|c|}
\hline Code & Treatments & $\begin{array}{l}\text { The weight of } \\
\text { rice biomass } \\
\text { (ton. ha }{ }^{-1} \text { ) }\end{array}$ & $\begin{array}{l}\text { The weight of } \\
\text { dried rice yield } \\
\text { (ton. } \text { ha }^{-1} \text { ) }\end{array}$ & $\begin{array}{l}\text { The weight of } \\
\text { dried grind } \\
\text { (ton. ha }{ }^{-1} \text { ) }\end{array}$ \\
\hline A & $\begin{array}{l}\text { Rice monoculture } \\
\text { (Farmer treatment) } \\
\text { Rice variety Ciherang }\end{array}$ & $12.09 \mathrm{c}$ & $6.75 \mathrm{c}$ & $5.46 \mathrm{c}$ \\
\hline B & $\begin{array}{l}\text { R-S cultivation } \\
\text { shrimp density } 4,000 \\
\text { Rice variety Inpari } 42\end{array}$ & $14.17 \mathrm{~b}$ & $9.16 \mathrm{~b}$ & $8.73 \mathrm{~b}$ \\
\hline $\mathrm{C}$ & $\begin{array}{l}\text { R-S cultivation } \\
\text { shrimp density } 6,000 \\
\text { Rice variety Inpari } 42\end{array}$ & $15.82 \mathrm{ab}$ & $9.86 \mathrm{~b}$ & $8.97 \mathrm{~b}$ \\
\hline $\mathrm{D}$ & $\begin{array}{l}\text { R-S cultivation } \\
\text { shrimp density } 8,000 \\
\text { Rice variety Inpari } 42 \\
\end{array}$ & $15.97 \mathrm{ab}$ & $10.12 \mathrm{a}$ & $9.28 \mathrm{a}$ \\
\hline $\mathrm{E}$ & $\begin{array}{l}\text { R-S cultivation } \\
\text { shrimp density } 4,000 \\
\text { Rice variety Inpari } 42+ \\
\text { Rice husk } 400 \mathrm{~kg}\end{array}$ & $14.82 \mathrm{~b}$ & $9.57 \mathrm{~b}$ & $8.64 \mathrm{~b}$ \\
\hline $\mathrm{F}$ & $\begin{array}{l}\text { R-S cultivation } \\
\text { shrimp density } 6,000 \\
\text { Rice variety Inpari } 42+ \\
\text { Rice husk } 400 \mathrm{~kg}\end{array}$ & $16.56 \mathrm{a}$ & $10.93 \mathrm{a}$ & $9.75 \mathrm{a}$ \\
\hline G & $\begin{array}{l}\text { R-S cultivation } \\
\text { shrimp density } 8,000 \\
\text { Rice variety Inpari } 42+ \\
\text { Rice husk } 400 \mathrm{~kg}\end{array}$ & $15.43 \mathrm{a}$ & $10.25 \mathrm{a}$ & $9.51 \mathrm{a}$ \\
\hline
\end{tabular}

* The numbers accompanied by the same letter in one column are not significantly different based on DMRT on the $5 \%$ level

Based on the data in Table 4, it showed that the weight of dried rice yield with the introduction of technology $\mathrm{F}$ treatment package (shrimp population 6,000 tails $/ 1000 \mathrm{~m}^{2}$ and plus rice husk charcoal $400 \mathrm{~kg}$ ) had the highest yield compared to other innovation packages and treatment package A (technolgy existing local farmers). This is due to the increasing number of shrimp populations until the optimum limit is able to increase soil fertility in paddy fields by increasing the amount of manure and left over shrimp food that is not consumed. So that the organic matter can be decomposed by microbes to add macro nutrients in irrigated rice fields, which are used as rice-shrimp cultivation ponds.

The researcher [40], declared that the density treatment population can be increased the yield of harvesting shrimp in the rice ponds provided that the conditions of rice field ecosystem including free pollution for irrigation water, $\mathrm{pH}$ water irrigation according to the required standard, availability of shelter for shrimp and adequate feed.

\subsection{The harvesting of shrimp on rice-shrimp cultivation based on its densities}

The rice-shrimp cultivation system can be an alternative to an ecological approach to sustainable farming systems without reducing the productivity of existing food crops, with rice plants as an ecological buffer [41]. The integration of the rice-shrimp system has not 
been well developed in Bantul Regency, even though the demand for shrimp in the market is quite high at a good price.

The local farmer mainly develop monoculture rice cultivation by local rice variety, with some traits : low yields ranging from 4.0 to 5.0 ton.ha ${ }^{-1}$ and it is not resistant to pest and diseases. Productivity of shrimp monoculture also remains low, ranging between 40 and 50 $\mathrm{kg} / 1,000 \mathrm{~m}^{2}$ in the paddy field area, as more than $90 \%$ of farmers still practise the traditional extensive method characterized by low stocking density, poor feed quality and water irrigated management.

On Table 5 it is presented the weight of harvesting shrimp on rice-shrimp cultivation in different denities stock. In treatment A did not get a shrimp harvest, because it only applied a monoculture system of planting rice without stocking shrimp in paddy fields. The highest shrimp yield was obtained on treatment $F$ (using rice variety Inpari 42, shrimp density population $6,000 / 1000 \mathrm{~m}^{2}$ plus rice husk charcoal $400 \mathrm{~kg}$ ) which was $85.72 \mathrm{~kg}$ and significantly different from other treatments but not different from treatment $G$ with a shrimp density population of $8,000 / 1000 \mathrm{~m}^{2}$. This indicates that the optimum density population of shrimp in the rice-shrimp cultivation system is 6,000 tails $/ 1,000 \mathrm{~m}^{2}$ on the aged 2 months.

This is in accordance with the opinion of Tahir dan Pasaribu [42], who stated that shrimp will grow well in a wide range of motion and well maintained ecosystem conditions., it showed from fresh weight /tails that the best results were in the treatment of rice-shrimp cultivation with shrimp density of 6,000 tails / plot and 8,000 tails $/ 1,000 \mathrm{~m}^{2}$ of irrigated rice fields.

Table 5. The weight of harvesting shrimp in different densities per $1,000 \mathrm{~m}^{2}$ of rice field

\begin{tabular}{|c|l|c|c|}
\hline Code & \multicolumn{1}{|c}{ Treatments } & $\begin{array}{c}\text { The weight of shrimp } \\
\text { (gr / tail) }\end{array}$ & $\begin{array}{c}\text { The weight of } \\
\text { harvesting shrimp } \\
\left(\mathrm{kg} / 1000 \mathrm{~m}^{2}\right)\end{array}$ \\
\hline A & $\begin{array}{l}\text { Rice monoculture } \\
\text { (Farmer treatment) } \\
\text { Rice variety Ciherang }\end{array}$ & Non \\
\hline B & $\begin{array}{l}\text { R-S cultivation } \\
\text { shrimp density 4,000 } \\
\text { Rice variety Inpari 42 }\end{array}$ & $27.86 \mathrm{a}$ & $57.18 \mathrm{a}$ \\
\hline C & $\begin{array}{l}\text { R-S cultivation } \\
\text { shrimp density 6,000 } \\
\text { Rice variety Inpari 42 }\end{array}$ & $26.75 \mathrm{a}$ & $75.64 \mathrm{~b}$ \\
\hline D & $\begin{array}{l}\text { R-S cultivation } \\
\text { shrimp density 8,000 } \\
\text { Rice variety Inpari 42 }\end{array}$ & $28.27 \mathrm{~b}$ & $78.35 \mathrm{~b}$ \\
\hline E & $\begin{array}{l}\text { R-S cultivation } \\
\text { shrimp density 4,000 } \\
\text { Rice variety Inpari 42 + Rice husk 400 kg }\end{array}$ & $30.54 \mathrm{c}$ & $85.58 \mathrm{ab}$ \\
\hline F & $\begin{array}{l}\text { R-S cultivation } \\
\text { shrimp density 6,000 } \\
\text { Rice variety Inpari 42 + Rice husk 400 kg }\end{array}$ & $30.22 \mathrm{c}$ \\
\hline G & $\begin{array}{l}\text { R-S cultivation } \\
\text { shrimp density 8,000 } \\
\text { Rice variety Inpari 42 + Rice husk 400 kg }\end{array}$ & $83.19 \mathrm{c}$ \\
\hline
\end{tabular}

* Numbers accompanied by the same letter in one column are not significantly different based on DMRT test on the level of $5 \%$ 


\subsection{The analysis of farming systems on rice-shrimp cultivation}

Presently, there are different types of culture systems practised for shrimp aquaculture in Bantul Regency, though most of the farmers follow traditional methods and generally do not practice well-defined rice field pond preparation, liming, fertilisation, predator control or artificial feeding. Where production is still low, water exchange is irregular, and water management irrigation is very poor.

The development of a sustainable rice-shrimp farming system must refer to the conditions of economic feasibility, local investment capacity and the level of adoption of local farming communities [43].

Net farm income is the difference between the output value of agricultural production reduced all costs incurred in a period of real period of production and of course its value of farm income must be greater than zero if it is to be stated profitable for farmers. In other words, the gross income from the harvest must be able to cover the total expenses per unit area of land.

The gross margin for each treatment was calculated based on average market prices and farm production. The cost included all inputs (rice seed, young shrimp, lime and inorganic fertilizers, plastic mulch, pralon pipe, net around the rice field), field preparation, labour, fuel for pumping irrigation water. The net return was calculated as the gross margin minus the cost. The benefit cost ratio (BCR) represents the gross margin divided by the cost.

On Table 6 it is shown the analysis of farming system on rice-shrimp cultivation and existing farmer as below. in treatment A (existing farmer), the total benefit obtained is IDR 2.235.000/1,000 $\mathrm{m}^{2}$ with a value of $\mathrm{BC}$ ratio 1.18 and $\mathrm{RC}$ ratio 2.18 , while the highest benefit was achieved by the package $\mathrm{F}$ (used inpari 42 rice variety and the shrimp density is $6,000 / 1000 \mathrm{~m} 2$ plus $400 \mathrm{~kg}$ rice husk charcoal) with a value of $\mathrm{BC}$ ratio 2.82 and $\mathrm{RC}$ ratio 3.82, followed by Package $\mathrm{E}$ treatment (used inpari 42 rice variety and the shrimp density is $4,000 / 1000 \mathrm{~m}^{2}$ plus $400 \mathrm{~kg}$ rice husk charcoal) with a value of $\mathrm{BC}$ ratio 2.57 and $\mathrm{RC}$ ratio 3.57. This can happen because the application of rice-shrimp cultivation in addition to obtaining a potentially high yielding of rice with the use of a new high yielding variety (Inpari 42), is also obtained by harvesting shrimp with optimum density (almost the same time with rice harvesting), so that a double benefit of rice and shrimp harvesting are obtained at a good price in the market.

According to Gupta et al. [44, 45,46] the farmer income and net profit of monoculture rice system is lower than that of rice-shrimp system. Actually, in the cultivation of rice shrimp, its shrimp is the main production target. While other products are treated as byproducts. Approximately 35 percent of gross return income arrive from by-products of the rice-shrimp farming system, which is less risky than the only shrimp farming system, because a certain portion of income was added from rice yield in rice-shrimp farming.

Moreover Rasowo et al. [47,48] explains that the rice-shrimp cultivation farming system generates more income larger than the rice monoculture system. However, when the disease is attacked, the rice monoculture system actually more profitable.

Furthermore Berg and Tam [49], stated that the problems faced in the development of rice-shrimp cultivation are the number of pests such as weasel, snakes, leaf hoppers and birds, the use of pesticides for rice pest and disease control. Pest attacks and excessive use of pesticides on rice plants can also affect the life of shrimp, causing farm production of rice-shrimp cultivation system was decreased. But if the environmental conditions are controlled, actually culturing shrimp in the rice fields can help control pests and weeds, promote nutrient availability to rice plants and enhance nutritional benefits and financial returns from what are widely regarded as low input, environmentally friendly and more sustainable farming systems $[50,51]$. 
Table 6. The analysis of economical farming system on Rice-Shrimp cultivation and existing farmer

\begin{tabular}{|c|c|c|c|c|c|c|c|}
\hline \multirow[b]{2}{*}{ Number } & \multirow[b]{2}{*}{ Description } & \multicolumn{6}{|c|}{ Rice - shrimp cultivation system } \\
\hline & & $\begin{array}{c}\text { Package } \\
\text { A }\end{array}$ & Package B & $\begin{array}{l}\text { Package } \\
\text { C }\end{array}$ & $\begin{array}{l}\text { Package } \\
\text { D }\end{array}$ & $\begin{array}{c}\text { Package } \\
\text { E }\end{array}$ & $\begin{array}{c}\text { Package } \\
\text { F }\end{array}$ \\
\hline & & IDR/ $0.1 \mathrm{ha}$ & IDR/ 0.1 ha & IDR/ 0.1 ha & $\begin{array}{l}\text { IDR/ } 0.1 \\
\text { ha }\end{array}$ & $\begin{array}{l}\text { IDR/ } 0.1 \\
\text { ha }\end{array}$ & $\begin{array}{l}\text { IDR/ } 0.1 \\
\text { ha }\end{array}$ \\
\hline \multicolumn{2}{|c|}{ A. Explicit Cost } & $1,265,000$ & $2,903,000$ & $3,563,000$ & $4,043,000$ & $3,143,000$ & $3,393,000$ \\
\hline I. & Production facilities & 665,000 & $2,263,000$ & $2,263,000$ & $3,343,000$ & $2,443,000$ & $2,693,000$ \\
\hline 1 & Seed $(3,0 \mathrm{~kg})$ & 60,000 & $\begin{array}{r}48,000 \\
1,200,000 \\
\end{array}$ & $\begin{array}{r}48,000 \\
1,800,000\end{array}$ & $\begin{array}{r}48,000 \\
2,400,000 \\
\end{array}$ & $\begin{array}{r}48,000 \\
1,600,000 \\
\end{array}$ & $\begin{array}{r}48,000 \\
1,800.000 \\
\end{array}$ \\
\hline \multirow[t]{4}{*}{2} & Fertilizer & & & & & & \\
\hline & Urea $(15 \mathrm{~kg})$ & 175,000 & 75,000 & 75,000 & 75,000 & 75,000 & 75,000 \\
\hline & $\begin{array}{l}\text { NPK 15:15:15 } \\
(20 \mathrm{~kg})\end{array}$ & 240,000 & 160,000 & 160,000 & 160,000 & 160,000 & 160,000 \\
\hline & $\begin{array}{l}\text { Organic fertilizer } \\
(300 \mathrm{~kg} /)\end{array}$ & 90,000 & 60,000 & 60,000 & 60,000 & 60,000 & 60,000 \\
\hline 3 & $\begin{array}{l}\text { Pesticides / } \\
\text { Shrimp feed }\end{array}$ & 100,000 & 500,000 & 560,000 & 600,000 & 500,000 & 550,000 \\
\hline II. & $\begin{array}{l}\text { External work } \\
\text { forces }\end{array}$ & 450,000 & 500,000 & 500,000 & 500,000 & 500,000 & 500,000 \\
\hline III. & Other costs & 150,000 & 200,000 & 200,000 & 200,000 & 200,000 & 200,000 \\
\hline \multicolumn{2}{|c|}{ B. Implisit Cost } & 250,000 & 350,000 & 350,000 & 400,000 & 350,000 & 350,000 \\
\hline IV. & $\begin{array}{l}\text { Internal / family } \\
\text { labour }\end{array}$ & 350,000 & 350,000 & 350,000 & 400,000 & 350,000 & 350,000 \\
\hline \multicolumn{2}{|c|}{ C. Total cost $(\mathrm{A}+\mathrm{B})$} & $1,615,000$ & $3,253,000$ & $3,913,000$ & $4,443,000$ & $3,493,000$ & $3,743,000$ \\
\hline \multicolumn{2}{|c|}{ D. Total income } & $3,850,000$ & $8,872,400$ & $12,161,200$ & $\begin{array}{r}12,663,00 \\
0\end{array}$ & $\begin{array}{r}11,761,00 \\
0\end{array}$ & $\begin{array}{r}13,982,00 \\
0\end{array}$ \\
\hline & $\begin{array}{l}\text { Yield of dried } \\
\text { rice yield }\end{array}$ & $2,700,000$ & $3,628,000$ & $4,160,000$ & $4,420,000$ & $4,590,000$ & $4,875,000$ \\
\hline & $\begin{array}{l}\text { Biomass of rice } \\
\text { yield }\end{array}$ & $1,150,000$ & $1,150,000$ & $1,950,000$ & $1,975,000$ & $2,000,000$ & $2,250,000$ \\
\hline & $\begin{array}{l}\text { Yield of harvested } \\
\text { shrimp }\end{array}$ & & $4,094,400$ & $6,051,200$ & $6,268,000$ & $5,166,400$ & $6,857,600$ \\
\hline \multicolumn{2}{|c|}{ E. Income (D-A) } & $2,585,000$ & $5,969,400$ & $8,598,200$ & $8,590,000$ & $9,018,000$ & $\begin{array}{r}10,589,00 \\
0\end{array}$ \\
\hline \multicolumn{2}{|c|}{ F. Benefid (D-C) } & $2,235,000$ & $5,619,400$ & $8,248,200$ & $8,220,000$ & $8,668,000$ & $\begin{array}{r}10,239,00 \\
0 .\end{array}$ \\
\hline \multicolumn{2}{|c|}{$\begin{array}{l}\text { G. Farming system feasibility } \\
\text { indicator }\end{array}$} & & & & & & \\
\hline \multicolumn{2}{|c|}{$\begin{array}{l}\text { 1. B/C (Rasio Benefid vs } \\
\text { Total cost), } \\
\text { Feasible }>1\end{array}$} & 1.18 & 1.73 & 2.10 & 1.93 & 2.57 & 2.82 \\
\hline \multicolumn{2}{|c|}{$\begin{array}{l}\text { 2. } \mathrm{R} / \mathrm{C} \text { (Rasio Income vs } \\
\text { Total cost), } \\
\text { Feasible }>2\end{array}$} & 2.18 & 2.74 & 3.10 & 2.93 & 3.57 & 3.82 \\
\hline
\end{tabular}

\section{Conclusions}

The productivity of irrigated rice fields by application of rice-shrimp cultivation in Bantul Regency will increase by distibuting the population of shrimp on a certain optimum density $\left(6,000\right.$ tails $\left./ 1,000 \mathrm{~m}^{2}\right)$. The culturing shrimp in paddy fields can help control pests and weeds, increase the availability of nutrients for rice plants and increase the content of organic matter derived from decomposition of feed residues and weeds as well as financial 
benefits for farmers with low inputs, and encourage environmentally friendly. The highest production of rice and shrimp on rice-shrimp cultivation is obtained by technology package $\mathrm{F}$ : using Inpari 42 rice variety, disributed shrimp population of 6,000 tails $/ 1,000 \mathrm{~m}^{2}$ plus $400 \mathrm{~kg}$ of rice husk charcoal to improve dried rice yield 9.75 ton. $\mathrm{ha}^{-1}$ and harvested shrimp $85.72 \mathrm{~kg} / 1,000 \mathrm{~m}^{2}$ and its significantly different from other treatments. The utilization of irrigated rice fields by development of rice-shrimp cultivation has economically feasible and improve net profit for the farmer, which is increased 3.58 times compared to rice monoculture system, this is indicated by the value of $\mathrm{BC}$ ratio of rice-shrimp innovation technology (Package F) becomes 2.82 and the $\mathrm{RC}$ ratio is 3.82 compare to the existing cultivation pattern of local farmer, that only have $\mathrm{BC}$ and $\mathrm{RC}$ ratios 1.18 and 2.17, respectively.

\section{References}

1. S. Widodo, Sarjono, Sudarmaji, Mulyadi dan S. Rustijarno. Laporan Akhir Kegiatan Analisis Kebijakan. Balai Pengkajian Teknologi Pertanian Yogyakarta. BBP2TP, Bogor. Balitbangtan. Unpublished .(2015).

2. S. Nuryanti dan K.S. Swastika.. Peran Kelompok Tani dalam Penerapan Teknologi Pertanian. Jurnal Forum Penelitian. Vol. 29 (2) : p.115-128. (2011)

3. Akbar. Peran Intensifikasi Mina Padi dalam Menambah Pendapatan Padi Sawah Di Gampong Gegarang Kecamatan Jagong Jeget Kabupaten Aceh Tengah. Jurnal Sosek Pertanian 1 (1): 28 - 38. (2017)

4. H. Berg. Rice Monoculture and Integrated Rice-fish Farming in The Mekong Delta, Vietnam-Economic and Ecological Considerations. Ecol. Econ. Vol. 41 : 95-107. (2002)

5. E. Marchezan, G.M. Telo, L. Golombieski, S.J. Lopes. Integrated Production of Irrigate Rice and Fish. Ciencia Rural 36, 411-417. (2006)

6. 6. J. Rasowo and E.O. Auma. On-Farm Trials with Rice-Fish Cultivation in The West Kano Rice Irrigation Scheme,Kenya. Naga-World Fish Center Quarterly.Vol. 29, No.1. (2006)

7. D. Dewani, M. Santoso dan T. Sumarni. Pengaruh Penggunaan Sistem Tanam dengan Pupuk Kompos Granul Diperkaya untuk Mengurangi Dosis Pupuk Anorganik pada Pertumbuhan dan Hasil Tanaman Padi (Oryza sativa). Jurnal Produksi Tanaman, Fakultas Pertanian-Universitas Brawijaya, Malang. 2 : 369-378. (2014)

8. S.R. Nadira, E. Syam'un dan D. Amirullah. Pertumbuhan dan Produksi Padi yang Diaplikasi Pupuk Organik dan Pupuk Hayati. Jurnal Agrivigor Vol. 11 (2): 161-170. (2012)

9. M. Halwart and M. V. Gupta. Culture of Fish in Rice Field. Published by FAO, Viale delle Terme di Caracalla, Rome-Italy and the World Fish Center, Penang-Malaysia. (2004)

10. O.R. Prasetyo dan Kadir. Teknik Penanaman Jajar Legowo untuk Peningkatan Produktivitas Padi Sawah di Jawa Tengah. Jurnal Litbang Sukowati Vol.3 (1) : 2840. (2019).

11. S. Abdulrachman, M. J. Mejana, N. Agustiani, I. Gunawan, P. Sasmita, dan A. Guswara. Sistem Tanam Legowo. Balai Besar Penelitian Padi-Sukamandi. Badan Litbang dan Pengembangan Pertanian Kementerian Pertanian. (2019).

12. Khoo, Khay Huat and E.S.P. Tan. Review of Rice-fish Culture in Southeast Asia. In Proceedings of the ICLARM-SEARCA Conference on Integrated Agriculture 
Aquaculture Farming Systems, Sponsored by International Center for Living Aquatic Resources Management, Southeast Asian Regional Center for Graduate Study and Research in Agriculture (ICLARMSEARCA), Manila. (1980).

13. A. Damayanti. Strategi Pengembangan Usaha Ugadi pada Kelompok tani pada Kelompok tani Mina Bakti Desa Pasir Doton, Kec. Ciduhar, Sukabumi. Skripsi. Depart. Agribisnis-Fakultas Ekonomi dan Manajemen IPB. (2013)

14. M. J. Kabir, R. Cramb and M. Alauddin. Farming Adaptation to Environmental Change in Coastal Bangladesh : Shrimp Culture versus Crop Diversification. Australian Agricultural and Resource Economics Society, Brisbane-Australia. (2015).

15. M.A. Chowdhury, Y. Khairun, M. Salequzzaman and M. M. Rahman. Effect of Combined Shrimp and Rice Farming on Water and Soil Quality in Bangladesh. Aquaculture International Journal. Vol. 19 : 1193-1206. (2011).

16. M. S. Allahyari and S.A. Noorhosseini. Agro-Economic Factors Determining on Adoption of Rice-Fish Farming : An Application for Artificial Neural Networks. Journal of Advanced Agricultural Technologies, Vol.1(2): 151-156. (2014)

17. X. Fan. Fish Culture in Rice Field : Rice - Fish Symbiosis in Rice-Fish Culture in China (Ed. Kenneth T. Mackey). International Development Research Centre-Ottawa, Canada. (1995)

18. F. Grassi, T.R. Paris, T. T. Ngoc Chi.. Rice-rice and Rice-Shrimp Production. A Gender Perpective on Labour, Time Use and Access to Technologies and Services in Southern Vietnam. Food and Agriculture Organization of the United Nations, Rome. (2017)

19. S. M. N Alam, Pokrant B., Yakupitiyage A., Phillips M. J. Economic Returns of Disease-Affected Extensive Shrimp Farming in Southwest Bangladesh. Aquac Int. Jour. 15 (5):363-370. (2007)

20. M.S. Islam. Socioeconomic Impacts of Alternate Shrimp-Shrimp-Crop Farming in Bangladesh. Technical Proc., BAU-NORAD Workshop, BRAC Centre, Dhaka, Bangladesh. p.61-78. (2003)

21. Sismiyati, Hermansah dan Y. Atmawita. Klasifikasi Beberapa Sumber Bahan Orgaik dan Optimalisasi Pemanfaatannya Sebagai Biochar. Jurnal Solum ISSN 2356-0835 : 8-16. (2018)

22. I. A. Janssens and S. Vicca. Biogeochemistry : Soil Carbon Breakdown. Nature Geoscience Journal, $3: 823-824$. (2010)

23. H. Wada, K. Inubushi, Y. Uehara, and Y. Takai. Easily Decomposable Organic Matter in Paddy Soils (I), Jour. Sci. Soil Manure, Japan, 52 : 246-252. (1981).

24. R.A. Nugroho, L.T. Pambudi, D. Chilmawati dan A. H.C. Haditomo. Aplikasi Teknologi Aquaponic pada Budidaya Ikan Air Tawar Untuk Optimalisasi Kapasitas Produksi. Jurnal Saintek Perikanan-Semarang Vol. 8. No.1. (2012).

25. J. Romanya, N. Arco, I. Sola-Morales, L. Armengot and F.X. Sans. Carbon and Nitrogen Stocks and Nitrogen Mineralization in Organically Managed Soils Amended with Composted Manures. J. Environ. Qual., 41: 1337-1347. (2011).

26. W. Cheng, A. T. Padre, C. Sato, H. Shiono, S. Hattori, A. Kajihara, M. Aoyama, K. Tawaraya and K. Kumagai. Changes in The Soil $C$ and $N$ Contents, C Decomposition and $N$ Mineralization Potentials in a Rice Paddy after Long-term Application of Inorganic Fertilizers and Organic Matter. Soil Science and Plant Nutrition Journal. Vol. 62 (2) : 212-219. (2016) 
27. W. De Boer and G.A. Kowalchuk. Nitrification in Acid Soils: Micro-Organisms and Mechanisms. Soil Biology and Biochemistry J. Vol. 33 : 853-866. (2001)

28. A. Nurhayati, W. Lili, T. Herawati and I. Riyantini. Derivatif Analysis of Economic and Social and Social Aspect of Added Value Mina-padi (Paddy-Fish Integrative Farming) a Case Study in The Village of Sagaracipta Ciparay Sub District, BandungWest Java Province, Indonesia. (2016).

29. E. Istiyanti. Assessing Farmers' Decision-Making in the Implementation of Jajar Legowo Planting System in Rice Farming Using a Logit Model Approach in Bantul Regency, Indonesia. E3S Web of Conferences 232, 01013. (2021)

30. Ikhwani, G. R. Pratiwi, E. Paturrohman dan A. K. Makarim.. Peningkatan Produktivitas Padi Melalui Penerapan Jarak Tajarwo. Iptek Tanaman Pangan Vol. 8 (2) : 72-79. (2013)

31. D. Susilastuti, Aditiameri, U. Buchori. The Effect of Jajar Legowo Planting System on Ciherang Paddy Varieties. Agritropica : Journal of Agricultural Science. Vol.1(1): 1-8. (2018).

32. R. Asnawi, R.W. Arief, Slamet, R. D. Tambunan, Martias, M. J. Mejaya and Fitriani. Increasing Rice (Oryza sativa L.) Productivity and Farmer's Income through the Implementation of Modified Double Rows Planting System Annual Research \& Review in Biology. Vol. 36(8): 42-52. (2021)

33. Husana. Pengaruh Penggunaan Jarak Tanam Terhadap Pertumbuhan dan Produksi Padi Sawah (Oryza sativa L.) Varietas IR 42 dengan Metode SRI (System of Rice Intensification). Jurnal Jurusan Agroteknologi. Fakultas Pertanian. Universitas Riau. (2010).

34. H. Ando, K. Kakuda, H. Fujii, K. Suzuki and T. Ajiki. Growth and Canopy Structure of Rice plants Grown Under Field Conditions as Affected by Si Application. Soil Sci. Plant Nutrition. Vol. 48 (3) : 429-432. (2002)

35. Gardner, Pearce and R. L Mitchell.. Fisiologi Tanaman Budidaya. UI Press. Jakarta. (2001)

36. M. Siavoshi, A. Nasiri, S. L. Laware. Effect of Organic Fertilizer on Growth and Yield Components in Rice (Oryza sativa L.). Journal of Agricultural Science Vol. 3 (3). (2011)

37. Sitohang. Evaluasi Pertumbuhan dan Produksi Beberapa Varietas Padi Gogo (Oryza sativa L.) pada Beberapa Jarak Tanam yang Berbeda. Jurnal Online Agroteknologi Vol. 2 : 2337-2347. (2014).

38. Z. M. Tilahun. Effect of Row Spacing and Nitrogen Fertilizer Levels on Yield and Yield Components of Rice Varieties. World Scientific News. An International Scientific Journal. Vol. $116: 180-193$. (2019)

39. Misran. Studi Sistem Tanam Jajar legowo Terhadap Peningkatan Produktivitas Padi Sawah. Jurnal Penelitian Pertanian Terapan Vol. 14 (2):106-110. (2014)

40. Ciyo, M. B. Efektivitas Bahan Organik dan Tinggi Genangan Terhadap Perubahan Eh, Ph, dan Status Fe, P, Al Terlarut Pada Tanah Ultisol. Jour. Agroland Vol.15 (4) : 257 - 263. (2008).

41. D. Brennan, N. Preston, H. Clayton and T.T. Be. An Evaluation of Rice-Shrimp Farming Systems in The Mekong Delta. Report prepared under the World Bank, NACA, WWF and FAO Consortium Program on Shrimp Farming and the Environment. Published by the Consortium, Bangkok. (2002). 
42. A.G. Tahir dan A.M. Pasaribu. Kajian Adaptasi Udang Galah (Macrobrachium rosenbergii) dan Ikan Mas (Cyprinus carpio) Dengan Sistem Mina Padi Jajar Legowo di Lahan Sawah Irigasi. Jurnal Pengkajian dan Pengembangan Teknologi Pertanian Vol. 6 (2) : 167-175. (2003).

43. M.A. Chowdhury, Y. Khairun, M.M. Rahman and G.P. Shivakoti. Production Economics as An Indicator for Sustainable Development of Shrimp Farming. Asia Pasific Journal of Rural Development Vol. 20 (1) : 79-97. (2010).

44. M.V. Gupta, J.D. Sollows, M.A. Mazid, A. Rahman, M.G. Hussain and M.M. Dey Integrating Aquaculture with Rice Farming in Bangladesh: Feasibility and Economic Viability, Its Adoption and Impact. ICLARM Technical Report 55. ICLARM, Metro Manila. (1998)

45. A.M.S. Ali. Rice to Shrimp: Land Use/ Land Cover Changes and Soil Degradation in Southwestern Bangladesh. Land Use Policy 23(4):421-435.(2006)

46. N.C. Thanh and T.T. Tuyet Van. Linking Farmers and Businesses in Integrated Organic Rice and Shrimp Farming - The Best Way for Enhancing Farmer's Income and Sustainable Agriculture Development. Agricultural Extension Journal Vol.3 (1) : 58-66. (2019)

47. J. Rasowo, E.O. Auma, M. Odhiambo and W. Kouko. Integrating Rice and Fish Farming to Improve Food Production and Income of Small Scale Farmers in West Kano, Kenya. AICAD Research Mini Reviews Vol.1. (2003).

48. T. G. Vanessa. Analisis Pendapatan Usahatani Padi Sawah Menurut Sistem mina padi dan Sistem non mina padi. Skripsi. Fakultas Pertanian, Institut Pertanian Bogor. Unpublised. (2008).

49. H. Berg and N.T. Tam. Use of Pesticides and Attitude to Pest Management Strategies Among Rice and Rice-fish Farmers in The Mekong Delta, Vietnam. Journal of Pest Manage, Vol. 58 : 153-164. (2012).

50. S.W. Bunting, N. Kundu and N. Ahmed. Rice-shrimp Farming Ecocultures in The Sundarbans of Bangladesh and West Bengal, India. New Ecocultures Case Study. ICES, Biological Sciences, University of Essex, Colchester, United Kingdom. (2011)

51. M.S. Islam, M.A. Wahab and M. Tanaka. Seed Supply for Coastal Brackishwater Shrimp Farming : Environmental Impacts and Sustainability. Marine Pollution Bulletin Vol. 48 : p.7-11. (2006) 